\title{
A Note on the Early Effects of the Brexit and US Presidential Votes on REITs
}

\author{
Mark Schaub ${ }^{1}$ \\ ${ }^{1}$ Professor of Finance, Department of Economics and Finance, Stephen F. Austin State University, USA \\ Correspondence: Mark Schaub, Professor of Finance, Department of Economics and Finance, P.O. Box 13009, \\ SFA Station, Stephen F. Austin State University, Nacogdoches, TX 75962-3009, USA. Tel: 936-468-1505. \\ E-mail: schaubm@sfasu.edu
}

Received: March 20, 2020

Accepted: April 24, 2020

Online Published: May 5, 2020

doi:10.5539/ijef.v12n6p14

URL: https://doi.org/10.5539/ijef.v12n6p14

\begin{abstract}
The votes for Brexit and the US President that occurred in June and November of 2016 took some investors by surprise. Markets reacted around the world with some countries, currencies and industries being affected more than others. This note finds US REITs significantly outperformed the S\&P 500 market index on the day of both elections. However, during the event windows starting 5 days before each vote until 5 days after, results are significant but mixed. These results may indicate REIT investment returns are uncorrelated with market index returns influenced by certain national events.
\end{abstract}

Keywords: REITs, portfolio diversification, early wealth effects, event studies

JEL classification: G11; G12; G14; G15.

\section{Introduction}

Recent event studies regarding the 2016 Brexit and US Presidential votes' impacts on stock and currency markets suggest investors believed those elections would have consequences. Schaub (2017a, 2017b, 2019a, 2019b) found UK and Mexican ADRs, as well as the Great Britain Pound and Mexican Peso, showed obvious value adjustments after the election results were made known. Another study by Schaub and Phares (2019) found little to no election-related effects on cryptocurrency values. This brief study examines short-term changes in the value of US REITs to determine whether these vote outcomes significantly impacted the wealth of REIT investors. A brief literature review follows in the next section. Then the methods and results are presented. The note is concluded in the final section.

\section{Literature Review}

Event studies have been around a long time beginning, perhaps, with the Harkavy (1953) examination of the effect of dividend announcements on stock prices. In recent times, more technology and speed of information flow seems to cause an abundance of the market overreaction first suggested by DeBondt and Thaler $(1985,1987)$. As markets have become more affected by computer trading, rather than people trading, volatility has increased as well.

Table 1. Event studies dealing with asset price reactions to recent national elections

\begin{tabular}{|c|c|}
\hline Schaub (2017a) & UK ADRs decreased in value after the announcement of the Brexit vote results \\
\hline Schaub (2019a) & $\begin{array}{l}\text { ar post-Brexit vote, UK ADRs had performed the same as the FTSE but underperformed the S\&P } 500 \text { by } \\
\text { ent }\end{array}$ \\
\hline Schaub (2017b) & ADR and currency values decreased upon the announcement of the 2016 US Presidential vote results \\
\hline Scha & $\begin{array}{l}\text { st-US Presidential election, Mexican ADRs underperformed the S\&P } 500 \text { by } 19 \text { percent after one year and } 41 \\
\text { cent after two years }\end{array}$ \\
\hline Scha & ns lost short term value after the Brexit vote results but did not react to the US Presidential vote \\
\hline Scha & $\begin{array}{l}\text { One year following the Brexit vote, oil and gas firms returned } 9 \text { percent versus } 21 \text { percent for the S\&P 500; one } \\
\text { year following the US Presidential vote, oil and gas firms broke even while the S\&P } 500 \text { returned } 15 \text { percent }\end{array}$ \\
\hline Schaub and Phares & $\begin{array}{l}\text { While no real evidence of correlated price movements between cryptocurrencies and market reactions to } \\
\text { elections were noted, close to the elections the volatility of cryptocurrencies was higher than the previous year } \\
\text { for the Brexit vote but less volatile than the previous year for the US Presidential election }\end{array}$ \\
\hline Benton and Philips (2020) & President Donald Trump's tweets about Mexico-related policies caused volatility in the Peso market \\
\hline
\end{tabular}


Because this study examines the impacts on REITs resulting from the June 2016 Brexit vote and the November 2016 US Presidential election outcome, Table 1 lists relevant studies examining reactions to these events. The studies mainly address country-related impacts but also look at the oil and gas industry and cryptocurrency values.

Other popular event studies include the seminal paper by Ball and Brown (1968) showing earnings releases affect stock prices and the Fama et al. (1969) study suggesting stock splits provide new useful information about a company. Other Brexit-related articles such as Holbolt (2016), Belke et al. (2018), and Burdekin et al. (2018) find the vote had past and potential future impacts on the financial markets of the UK and European Union.

While most studies examine overall market effects on equities and currencies, the industry-specific studies focused on energy more relevantly tie in to this study. Recent stock market performance in the US has been driven mostly by high capitalized volatile industries as these market increases unequally reflect the values of a few firms (called FAANG for Facebook, Apple, Amazon, Netflix and Google). Here the research question is whether significant reactions occurred in the US REIT market around the elections.

\section{Methodology}

The REITs utilized in this study were taken from the Morningstar list of US REITs listed on the NYSE. From this list, 137 REITs had data available for the June 23, 2016 Brexit vote and the November 8, 2016 US Presidential election.

Average returns (AR) are computed each day for the portfolio of 137 NYSE-traded REITs. Equations 1 and 2 below illustrate how excess returns (xr) and average excess returns (XR) are calculated for each day during the event windows beginning 5 days before and ending 5 days after the elections. In Equation 1, the return for each REIT $i$ on day $t\left(r_{i t}\right)$ is subtracted from the $S \& P 500$ index return on that day $\left(r_{m t}\right)$ to get the excess return of the $\operatorname{REIT}\left(\mathrm{xr}_{\mathrm{it}}\right)$.

$$
x r_{i t}=r_{i t}-r_{m t}
$$

In Equation 2, the sum of the excess returns are divided by 137 to get the average excess return (XR) of the REIT portfolio.

$$
X R_{t}=\frac{1}{n}\left[\sum_{i=1}^{n} x r_{i t}\right]
$$

Both, the average returns (AR) and average excess returns (XR) computed for each day of the event window, are tested for statistical significance (the respective P-values are provided). The event windows surround the election dates of June 23, 2016 and November 8, 2016 (day 0). The results for five days before and five days after the election define the window $[-5,5]$.

\section{Results}

The results of the study are presented in Table 2. The table consists of two panels comparing the REIT portfolio returns to those of the S\&P 500 based on each election event. The bolded date represents when the election occurred, although the main market reaction may have occurred on the following day.

In Panel 1, the value changes of REITs are compared to that of the S\&P 500 before, during and after the Brexit vote. The REITs appear to have outperformed the index all but one day from the day of the election onward. The most significant excess performance was on the day of the vote when the REITs outperformed the S\&P 500 index by 4.26 percent. REIT valuations were more volatile and positive the last three days of the event window related to the Brexit vote. Also, the REIT value results appear to lag that of the S\&P 500 (if the daily REIT returns are moved back one day they mimic the directional change of the S\&P 500 most days).

Panel 2 of the table shows how the REITs performed after the US Presidential vote. On the day of the election the REIT portfolio performed a little better than the market index; however, the two days after the election, REITs lost value while the S\&P 500 increased causing the REITs to significantly underperform the market index. For each of the 5 days after the election, REIT values changed opposite the market index, resulting in significant underperformance or outperformance all 5 days. Finally, the day before the election, both the REITs and market index gained significant value. Overall, it appears the S\&P 500 value reaction to the election was more favorable than that of the REITs for 4 days around the election window $[-1,+2]$. 
Table 2. Brexit and US election vote effects on REITs

\begin{tabular}{|c|c|c|c|c|c|}
\hline \multicolumn{6}{|c|}{ Panel 1. REITS versus the S\&P 500 Index (BREXIT vote) } \\
\hline date & AR REITs & P-Value & S\&P 500 Ret & XR REITs - S\&P 500 & P-Value \\
\hline 2016-06-16 & $0.39 \%$ & 0.00 & $-0.33 \%$ & $0.72 \%$ & 0.00 \\
\hline 2016-06-17 & $0.11 \%$ & 0.13 & $0.58 \%$ & $-0.47 \%$ & 0.00 \\
\hline 2016-06-20 & $0.15 \%$ & 0.01 & $0.27 \%$ & $-0.12 \%$ & 0.02 \\
\hline 2016-06-21 & $0.16 \%$ & 0.01 & $-0.17 \%$ & $0.33 \%$ & 0.00 \\
\hline 2016-06-22 & $-0.28 \%$ & 0.00 & $1.34 \%$ & $-1.62 \%$ & 0.00 \\
\hline 2016-06-23 & $0.67 \%$ & 0.00 & $-3.59 \%$ & $4.26 \%$ & 0.00 \\
\hline 2016-06-24 & $-0.90 \%$ & 0.00 & $-1.81 \%$ & $0.91 \%$ & 0.00 \\
\hline 2016-06-27 & $-0.73 \%$ & 0.00 & $1.78 \%$ & $-2.51 \%$ & 0.00 \\
\hline $2016-06-28$ & $2.14 \%$ & 0.00 & $1.70 \%$ & $0.44 \%$ & 0.00 \\
\hline 2016-06-29 & $1.38 \%$ & 0.00 & $1.36 \%$ & $0.02 \%$ & 0.44 \\
\hline 2016-06-30 & $1.19 \%$ & 0.00 & $0.19 \%$ & $1.00 \%$ & 0.00 \\
\hline \multicolumn{6}{|c|}{ Panel 2. REITS versus the S\&P 500 Index (US Presidential vote) } \\
\hline date & AR REITs & P-Value & S\&P 500 Ret & XR REITs - S\&P 500 & P-Value \\
\hline 2016-11-01 & $-2.18 \%$ & 0.00 & $-0.68 \%$ & $-1.50 \%$ & 0.00 \\
\hline 2016-11-02 & $-1.18 \%$ & 0.00 & $-0.65 \%$ & $-0.53 \%$ & 0.00 \\
\hline 2016-11-03 & $-0.34 \%$ & 0.00 & $-0.44 \%$ & $0.10 \%$ & 0.17 \\
\hline 2016-11-04 & $0.69 \%$ & 0.00 & $-0.17 \%$ & $0.86 \%$ & 0.00 \\
\hline 2016-11-07 & $1.64 \%$ & 0.00 & $2.22 \%$ & $-0.58 \%$ & 0.00 \\
\hline 2016-11-08 & $0.59 \%$ & 0.00 & $0.38 \%$ & $0.21 \%$ & 0.01 \\
\hline 2016-11-09 & $-0.18 \%$ & 0.33 & $1.11 \%$ & $-1.29 \%$ & 0.00 \\
\hline 2016-11-10 & $-1.24 \%$ & 0.00 & $0.20 \%$ & $-1.44 \%$ & 0.00 \\
\hline 2016-11-11 & $1.23 \%$ & 0.00 & $-0.14 \%$ & $1.37 \%$ & 0.00 \\
\hline 2016-11-14 & $1.68 \%$ & 0.00 & $-0.01 \%$ & $1.69 \%$ & 0.00 \\
\hline 2016-11-15 & $-0.66 \%$ & 0.00 & $0.75 \%$ & $-1.41 \%$ & 0.00 \\
\hline
\end{tabular}

Note. AR is the average return on each day for the REITs. XR is the average excess returns of the REITs and the S\&P 500 index. The Brexit vote took place June $23^{\text {rd }}$ and the Presidential vote occurred on November $8^{\text {th }}$ (markets reacted once the results were released on November $\left.9^{\text {th }}\right)$. Prior dates show anticipatory reactions while days after the election results show further reactions.

\section{Conclusions}

The study examined whether the vote to leave the European Union by the UK or the US Presidential election vote (both held in 2016) had any significant short-term wealth impacts on NYSE-traded REITs. While the S\&P 500 clearly reacted negatively at first then turned positive after the Brexit vote, there was no discernable reaction by REITs even though the returns during the event window were significant nearly every day. However, on the day of the vote, REITs significantly outperformed the S\&P 500 by over 4 percent, mainly because the index lost a lot of value that day.

Around the US election vote the S\&P 500 was in positive territory from the day before until two days after the election. The REITs however showed mixed results (the day before and the day of the election REIT returns were positive and then the next two days they were negative). Around the day of the election (one day before until two days after), REITs pretty much underperformed the S\&P 500 index overall.

Overall, this research adds to event study literature by showing that REITs tend to behave independently of the market portfolio in response to significant national votes. While many researchers would prefer a specific, obviously positively or negatively correlated result, the lack thereof does provide evidence that some industries and/or investment types are not always impacted by such events.

\section{References}

Ball, R. J., \&Brown, P. (1968). An empirical evaluation of accounting income numbers. Journal of Accounting Research, 6, 159-178. https://doi.org/10.2307/2490232

Belke, A., Dubova, I., \& Osowski, T. (2018). Policy Uncertainty and International Financial Markets: The Case of Brexit. Applied Economics, 50(34-35), 3752-3770. https://doi.org/10.1080/00036846.2018.1436152

Benton, A., \& Philips, A. (2020). Does the @RealDonaldTrump Really Matter to Financial Markets? American Journal of Political Science, 64(1), 169-190. https://doi.org/10.1111/ajps.12491 
Burdekin, R., Hughson, E., \& Gu, J. (2018). A First Look at Brexit and Global Equity Markets. Applied Economics Letters, 25(2), 136-140. https://doi.org/10.1080/13504851.2017.1302057

DeBondt, W., \& Thaler, R. (1985). Does the Stock Market Overreact? Journal of Finance, 40(3), 793-805. https://doi.org/10.1111/j.1540-6261.1985.tb05004.x

DeBondt, W., \& Thaler, R. (1987). Further Evidence on Investor Overreaction and Stock Market Seasonality. Journal of Finance, 42(2), 557-581. https://doi.org/10.1111/j.1540-6261.1987.tb04569.x

Fama, E., Fisher, L., Jensen, M., \& Roll, R. (1969). The adjustment of stock prices to new information. International Economic Review, 10, 1-21. https://doi.org/10.2307/2525569

Harkavy, O. (1953). The Relation between Retained Earnings and Common Stock Prices for Large Listed Corporations. Journal of Finance, 3(1), 283-297. https://doi.org/10.1111/j.1540-6261.1953.tb01170.x

Hobolt, S. (2016). The Brexit Vote: A Divided Nation, A Divided Continent. Journal of European Public Policy, 23(9), 1259-1277. https://doi.org/10.1080/13501763.2016.1225785

Schaub, M. (2017a). Initial Wealth Effects of the Brexit Vote on UK ADRs. Applied Economics Letters, 24(17), 1232-1236. https://doi.org/10.1080/13504851.2016.1270398

Schaub, M. (2017b). A Note on the Early Effects of the US Presidential Vote on Mexican ADR Values. Journal of Asset Management, 18(7), 511-515. https://doi.org/10.1057/s41260-017-0043-x

Schaub, M. (2017c). Energy Stock Price Reactions to the Brexit Vote and the US Presidential Election. Oil, Gas \& Energy Quarterly, 65(4), 579-585.

Schaub, M. (2019a). The Brexit Effect: The Case of UK ADR Performance One Year Later. Applied Economics Letters, 26(1), 5-9. https://doi.org/10.1080/13504851.2018.1430330

Schaub, M. (2019b). US Presidential Election Effects on Mexican ADRs: A Two-Year Analysis. Applied Economic Letters, 26(20), 1709-1712. https://doi.org/10.1080/13504851.2019.1593313

Schaub, M. (2019c). Election Effects on Large Oil and Gas Firms One Year Later. Oil, Gas \& Energy Quarterly, 47(4), 633-638.

Schaub, M., \& Phares, H. B. (2019). Cryptocurrency Value Changes in Response to National Elections: Do They Behave Like Mon-ey or Commodities? Applied Economics Letters. https://doi.org/10.1080/13504851.2019.1673297

\section{Copyrights}

Copyright for this article is retained by the author(s), with first publication rights granted to the journal.

This is an open-access article distributed under the terms and conditions of the Creative Commons Attribution license (http://creativecommons.org/licenses/by/4.0/). 